\title{
Evaluation of elderly persons' functionality and care needs ${ }^{1}$
}

\author{
Manuel José Lopes ${ }^{2}$ \\ Ana Escoval ${ }^{3}$ \\ Dulce Gamito Pereira ${ }^{4}$ \\ Carla Sandra Pereira ${ }^{5}$ \\ Catarina Carvalho ${ }^{6}$ \\ César Fonseca ${ }^{7}$
}

Objective: To evaluate the elderly persons' functionality, based on the International Classification of Functionality. Methods: a cross-sectional, descriptive study; a stratified random sample of 903 elderly persons; a confidence level of 95\%; and a margin of error of $2.5 \%$. Questionnaire based on the International Classification of Functionality; data was collected based on structured interviews undertaken by health professionals in the health centers in the Alentejo region of Portugal. Results: $30.7 \%$ of the elderly persons stated that they were illiterate, and $22.9 \%$ lived alone. Feeding/dietary (18.7\%), housing (19.2\%) and health needs $(26.0 \%)$ were not met. Orientation functions were maintained in $83.4 \%$; $58 \%$ of the elderly persons referred to pain so intense that it required care; $73.3 \%$ of the elderly persons did not have functional dentition. Levels of performance were superior to $80 \%$ in the participation activities: washing oneself (82.6\%), toileting (92.2\%), dressing, eating, and drinking (89\%). Conclusion: although a progressive decline in functionality is observed as age advances, the majority of dimensions are preserved until around 75 years of age.

Descriptors: Aging; International Classification of Functioning, Disability and Health; Needs Assessment.

\footnotetext{
1 This research was supported by Alto Comissariado da Saúde, Portugal.

2 PhD, Coordinator Profesor, Escola Superior de Enfermagem de São João de Deus, Universidade de Évora, Portugal.

${ }^{3}$ PhD, Assistant Professor, Escola Nacional de Saúde Pública, Universidade Nova de Lisboa, Portugal.

${ }^{4} \mathrm{PhD}$, Assistant Professor, Escola de Ciências e Tecnologias, Universidade de Évora, Portugal.

${ }^{5}$ Doctoral Student, Instituto Politécnico de Castelo Branco, Portugal.

${ }^{6}$ Doctoral Student, Escola Nacional de Saúde Pública, Universidade Nova Lisboa, Portugal.

7 Doctoral Student, Centro Hospitalar Lisboa Norte, Portugal.
} 


\section{Avaliação da funcionalidade e necessidades de cuidados dos idosos}

Objetivo: avaliar a funcionalidade dos idosos com base na Classificação Internacional da Funcionalidade. Métodos: estudo transversal, descritivo; amostra aleatória, estratificada, com 903 idosos; nível de confiança 95\%; margem de erro 2,5\%. Questionário desenvolvido com base na Classificação Internacional da Funcionalidade; dados coletados a partir de entrevista estruturada por profissionais de saúde nos centros de saúde do Alentejo. Resultados: 30,7\% dos idosos declaram-se analfabetos, $22,9 \%$ vivem sozinhos. As necessidades de alimentação $(18,7 \%)$, habitação $(19,2 \%)$ e saúde $(26,0 \%)$ não estão satisfeitas. Funções de orientação preservadas em $83,4 \% ; 58 \%$ dos idosos referem uma intensidade de dor que requer cuidados; $73,3 \%$ dos idosos não apresentam dentição funcional. Níveis de desempenho superior a $80 \%$ nas atividades de participação: lavar-se $(82,6 \%)$, atividades relacionadas ao processo de excreção $(92,2 \%)$, vestir, comer, beber $(89 \%)$. Conclusão: decréscimo progressivo da funcionalidade à medida que a idade avança; todavia, está preservada em grande parte as dimensões até cerca dos 75 anos.

Descritores: Envelhecimento; Classificação Internacional de Funcionalidade, Incapacidade e Saúde; Determinação das Necessidades de Cuidados de Saúde.

\section{Evaluación del funcionamiento y necesidades de cuidados de los ancianos}

Objetivo: Evaluar la funcionalidad de los ancianos basado en la Clasificación Internacional del Funcionamiento. Métodos: Estudio transversal, descriptivo; muestra aleatorizada, estratificada con 903 ancianos; nivel de confianza 95\%; margen de error 2,5\%. Cuestionario desarrollado basado en la Clasificación Internacional del Funcionamiento; datos recolectados a partir de entrevista estructurada por profesionales de salud en los Centros de Salud del Alentejo. Resultados: el $30,7 \%$ de los ancianos se declara analfabeto, 22,9\% vive solo. Las necesidades de alimentación $(18,7 \%)$, habitación $(19,2 \%)$ y salud $(26,0 \%)$ no están atendidas. Funciones de orientación preservadas en el $83,4 \%$; el $58 \%$ de los ancianos indica una intensidad de dolor que demanda cuidados; el $73,3 \%$ de los ancianos no demuestra dentición funcional. Niveles de desempeño superiores al $80 \%$ en las actividades de participación: lavarse $(82,6 \%)$, actividades relacionadas al proceso de excreción (92,2\%), vestir, comer, beber (89\%). Conclusión: Disminución progresivo del funcionamiento con el avance del edad, aunque sigue preservada grande parte de las dimensiones hasta acerca del edad de 75 años.

Descriptores: Envejecimiento; Clasificación Internacional del Funcionamiento, de la Discapacidad y de la Salud; Evaluación de Necesidades.

\section{Introduction}

Demographic ageing is a global reality, although it is more evident in some countries than others ${ }^{(1)}$. The population aged over 65 is going to have an exponentially greater demographic representativeness ${ }^{(1-2)}$. This population is associated with negative social perceptions and incapacity ${ }^{(3-4)}$, as well as with an increase in costs and social resources to the health services ${ }^{(3,5)}$. This is because, according to some studies( ${ }^{(6)}$, elderly people have a high prevalence of chronic illness, with multimorbidity predominating.
A set of reasons for this phenomenon are habitually presented, among which the authors highlight the association between the constant increase in life expectancy at birth* and the reduction in the synthetic fertility index**. Life expectancy at birth, at a global level, passed 47.7 years in 1950, rising to 69.3 in 2010. In some, more 'elderly' countries (e.g. Portugal), the average life expectancy has already reached 79.8 years (76.7 for men, 82.8 for women), while the synthetic fertility index is 1.37 children per woman ${ }^{(7)}$.

\footnotetext{
* The average number of years that a newborn can expect to live, if subject throughout his or her life to the current conditions of mortality (Eurostat). ** The average number of children born alive to a woman during her life if she passes through her fertile years, with the rates observed on the mentioned date maintained constant (National Institute of Statistics - meta-information).
} 
In Portugal, in 2001, the proportion of people aged 65 or over was $19 \%$, whereas a decade previously it had been $16 \%{ }^{(8)}$. The results of the 2011 Census indicate that the country's rate of ageing is 129 (129 elderly people for 100 young people) ${ }^{(8)}$. In the last decade, the dependency ratio rose from 48 in 2001 to 52 in 2011. The exacerbation of the total dependency ratio is the result of the rise in the rate of dependency of elderly people, which increased by approximately $21 \%$ over the last decade ${ }^{(8)}$. The Alentejo is the region of Portugal which has the highest ageing index (179), representing an elderly population which is $25.3 \%$ of the total. It was for these reasons that the authors chose this region to carry out their research.

For this reason one is confronted by a new context which has repercussions for all levels of society: the health system needs to be prepared conceptually, organizationally and logistically for a rising demand for care, from a population with differing characteristics.

It is, therefore, important to pose the following questions: How should elderly people's care needs be evaluated? Centered on the illnesses and resulting incapacities, or in the remaining capacities for meeting their needs in context?

Functional status, as well as being an indicator for health status, is an excellent indicator for predicting health care's costs and resources ${ }^{(5,9)}$. A person's functionality and incapacity are understood as a dynamics interaction between the states of health (e.g., illnesses, disorders, lesions, traumas) and the contextual factors. In order to classify functionality, the World Health Organization (W.H.O) created the International Classification of Functionality (ICF), which was adopted by Portugal(4) and whose use is recognized as bringing various advantages. The incapacity indicators - namely, those to do with limitation of activity and limitation of functional capacity - allow the subsequent definition of health care needs ${ }^{(10)}$. For this reason, it is important to develop an instrument for evaluating elderly people's functionality ${ }^{(11-12)}$, based in a classification whose general objective is to permit a unified, standardized language, as well as a working structure for the description of health and states related to health. It was based in this classification that the authors undertook the development of the Elderly Core Set ${ }^{(13)}$.

In this context, the authors proposed to carry out a study based in the following question: What is the epidemiological profile of functionality of the population aged 65 or over, resident in Alentejo?
The study objectives were: Evaluate the functionality of the population aged 65 or over, resident in Alentejo, based in the International Classification of Functionality (ICF); Indicate the functional limitations of the population aged over 65 and resident in Alentejo.

\section{Method}

In terms of methodology, the present study is cross-sectional and descriptive.

The sample was composed of people aged over 65 years old on the 31st of January 2011 (inclusive), registered in the data bases of the Alentejo Regional Health Administration (excluding Lezíria). For defining the sample's dimension, the authors considered data available on the site of the National Institute of Statistics (NIS) on the resident population for the region, at the level of NUTS* II, sex and age group (65-74; 75-84; 85 years and over). The reference period for the data is 2009, as these were the most recent available from the NIS at the time. A confidence level of $95 \%$ and a margin of error of $2.5 \%$ were taken into account, and a sample of 1518 individuals over 65 years of age, of both sexes, resident in the region of Alentejo, was identified. The following criteria were used for stratifying the sample: age groups $(65-74,75-84,+85)$; sex; and area of residence.

The division of the total dimension of the sample by strata was achieved by Neyman's optimal allocation. The initial sizing of the sample was made considering the weighting of each strata in relation to its dimension in the sample and in relation to variability (the fact that the variance is unknown leads the authors to use maximum variance). The selection of the sample was effected, in each strata, through simple random selection without replacement, with use of random numbers in each strata. The health centers' data bases were used for the selection of the sample.

Data collection was undertaken by health care professionals using the technique of structured interview based on the Elderly Core Set. All of the health professionals had previously attended training in the valuation of functionality based in the ICF. They also received a manual on the use of the Core Set and the contact details for one of the researchers for clarification of any doubts.

The people selected for the sample were convened by the health professionals for the specified purpose

* Nomenclature of Territorial Units for Statistics of Portugal 
of evaluating functionality. In some cases, data was collected in the people's homes during home visits. On average, applying the questionnaire took 45 minutes. Data collection ran from June to December 2011.

The necessary ethical procedures were followed, namely the submitting of the study to the Research Ethics Commission of the Health Sciences faculty of the University of Évora and the obtaining of informed consent on the part of the participants in the study.

The data was analyzed using SPSS ${ }^{\circledR}$, making use essentially of descriptive statistics, with percentages, measurements of central tendency and dispersion and distribution being calculated mainly by age group. For the last case, the Chi-squared test, the Gamma measure of association and Somer's coefficient were used as a way of evaluating the statistical significance.

\section{Presentation of data}

Taking into account the dimension of the present study, only parceled data are presented. The authors will systematically provide evidence on the dimension of functionality and the dimension of incapacity, and the consequent care needs. The data was selected bearing in mind the most important care needs perceived by the authors.

\section{Socio-demographic characterization}

The final dimension of the sample was of 903 individuals, of whom $43.2 \%$ were male and $56.8 \%$ female, distributed across various age groups as may be verified in Table 1. After statistical analysis, it was determined that the difference compared to the initial sample is not significant.

Table 1 - Distribution of the sample by sex and age

\begin{tabular}{|c|c|c|c|c|c|}
\hline \multirow{2}{*}{\multicolumn{2}{|c|}{ Variables }} & \multicolumn{3}{|c|}{ Age - categorized (years) } & \multirow{2}{*}{ Tota } \\
\hline & & $65-74$ & $75-84$ & 85 and over & \\
\hline \multicolumn{6}{|l|}{ Sex } \\
\hline \multirow{2}{*}{ Male } & $\mathrm{n}$ & 163 & 180 & 47 & 390 \\
\hline & $\%$ & 18.1 & 19.9 & 5.2 & 43.2 \\
\hline \multirow{2}{*}{ Female } & $\mathrm{n}$ & 200 & 234 & 79 & 513 \\
\hline & $\%$ & 22.1 & 25.9 & 8.7 & 56.8 \\
\hline \multirow{2}{*}{ Total } & $\mathrm{n}$ & 363 & 414 & 126 & 903 \\
\hline & $\%$ & 40.2 & 45.8 & 14.0 & 100.0 \\
\hline
\end{tabular}

Regarding Level of schooling it was determined that $30.7 \%$ stated that they could neither read nor write, this percentage being predominantly female (21.5\%) and in the age groups $75-84$ and 85 years and over.
Regarding Close family network, 14.4\% did not have children, and approximately $23 \%$ of the elderly people - principally in the age range 75 - 84 years lived alone.

When questioned on self-evaluation of financial condition, $18.7 \%$ of the elderly persons stated that they could not meet their needs in terms of food; $19.2 \%$ said they could not meet their housing needs and $26 \%$ stated that they could not meet their health needs. In the face of this it is to be expected that they should know about and use social support resources, however, only $9.3 \%$ received the Senior Citizens Pension Supplement*, only $17.7 \%$ knew about the Dental Check Program and only $1.1 \%$ used it, in spite of $9.3 \%$ of them being immediately and directly entitled to it.

\section{Characterization of functionality and care needs}

Among the various Body functions, the researchers evaluated the global mental functions, in which the functions of orientation and sleep were highlighted. It was determined that in relation to the former, $94.6 \%$ of the elderly did not mention any problems. However, a total of $5.4 \%$ of the elderly responded in the affirmative to the two classes of response, which indicates a need for therapeutic care. The need for care is more evident in the individuals aged 85 or over ( $p$-value Chi-Square Tests $<0.001$ ).

It was determined that in regard to the sleep functions approximately $3 / 4 \quad(74.8 \%)$ of the elderly people did not mention any problems. The remaining quarter, however, (25.2\%) present a level of problems which requires care. There is, however, no significant association ( $p$-value Chi-Square Tests >0.05) between the functions of sleep and the age group.

Among specific mental functions, the authors highlight the functions of memory, in relation to which $73.3 \%$ of the elderly persons did not mention any difficulty. However, $26.7 \%$ present a level of difficulty which requires therapeutic care. These difficulties are mainly found among the individuals between 75 and 84 years old ( $p$-value Chi-Square Tests $<0.001$ ).

Among the sensory and pain functions, the authors highlight the hearing functions, in which $84.4 \%$ of the elderly persons did not mention difficulties, and $15.6 \%$ present a level of difficulties which require care, this being more evident in individuals aged between 75 and 84 ( $p$-value Chi-Square Tests <0.001).

Concerning the pain functions, the authors noticed that the majority of the elderly persons (58.2\%)

* Financial support paid monthly to elderly people with few financial resources. It is complementary to the pension which the elderly receive. 
presented an intensity of pain which required therapeutic care, but that this was not related to age. The most intense pain was located in the lumbar region, in the right knee, the posterior region of the right leg and in the dorsal region.

Among the Body structures evaluated by the researchers, the structures of the mouth are highlighted, namely the teeth. It was ascertained that only $26.7 \%$ of the elderly persons had functional dentition, that is, that they had at least twenty anterior teeth in occlusion, of which eight incisors, four canines and eight pre-molars are present, capped, or replaced with a false tooth; the remainder (73.3\%) did not have functional dentition. This distribution had no significant relationship with age.

Among the Activities and Participation evaluated, the authors will refer only to Reading, Writing, carrying out a Daily Routine, and Self-Care, emphasizing not only ability but also limitations.

Regarding the activity of Reading, it was determined that while $59.1 \%$ did not present any difficulty, or only a mild difficulty, $40.9 \%$ of the elderly persons presented a moderate-intense difficulty in reading $(2.8 \%)$ or complete difficulty (38.1\%). As for the activity of Writing, an identical phenomenon was observed, that is, $56.1 \%$ of the elderly people did not have difficulties, but that $43.9 \%$ had moderate-intense difficulty $(6.1 \%)$ or complete difficulty (7.8\%). In both cases, the difficulties were more significant in the age range of 75 to 84 years ( $p$-value Chi-Square Tests $<0.001$ ). The percentages of the elderly persons with moderate-intense and complete difficulty in these two activities (reading and writing) must be compared with the $30.7 \%$ of elderly persons who, in relation to education, state that they are unable to read and write.

Regarding the activity of Carrying out of Daily Routine, it was ascertained that a clear majority of $88.9 \%$ of the elderly persons did not present difficulties. However, $11.1 \%$ mentioned a level of difficulty requiring care, with particular predominance in the age range 75 - 84 years ( $p$-value Chi-Square Tests <0.001).

The researchers evaluated various activities belonging to the Self-care group (Table 2). Among these, the activity of washing oneself is emphasized, where it is determined that $95.7 \%$ of the elderly people did not present any difficulties but that $4.3 \%$ presented a level of difficulty requiring therapeutic care. In the activity of caring for body parts, $86 \%$ of the elderly persons did not mention difficulties, meaning that the percentage of those who presented difficulties requiring therapeutic help in this matter $(14.1 \%)$ is higher than for the activity of washing. In toileting, on the other hand, it was ascertained that $95.8 \%$ of the elderly people did not mention difficulties, which means that only $4.2 \%$ presented difficulties needing care. The percentage of people with difficulty in dressing themselves was $7.5 \%$. In the activity of eating, only $4.8 \%$ mentioned difficulties, and in the activity of drinking the figure was only $3.0 \%$. There is a statistically significant association with age in all the self-care activities ( $p$-value Chi-Square Tests $<0.001$ ), with difficulties being most evident in ages over 75 years.

Table 2 - Distribution of some activities of self-care in relation to age

\begin{tabular}{|c|c|c|c|c|c|}
\hline \multirow{2}{*}{ Variables } & & \multicolumn{3}{|c|}{ Age - categorized (years) } & \multirow{2}{*}{ Total } \\
\hline & & $65-74$ & $75-84$ & 85 and over & \\
\hline \multicolumn{6}{|l|}{ Washing oneself } \\
\hline \multirow{2}{*}{ No difficulty } & $n$ & 339 & 339 & 68 & 746 \\
\hline & $\%$ & $37.50 \%$ & $37.50 \%$ & $7.50 \%$ & $82.60 \%$ \\
\hline \multirow{2}{*}{ Moderate-weak difficulty } & $\mathrm{n}$ & 21 & 61 & 36 & 118 \\
\hline & $\%$ & $2.30 \%$ & $6.80 \%$ & $4.00 \%$ & $13.10 \%$ \\
\hline \multirow{2}{*}{ Complete difficulty } & $\mathrm{n}$ & 3 & 14 & 22 & 39 \\
\hline & $\%$ & $0.30 \%$ & $1.60 \%$ & $2.40 \%$ & $4.30 \%$ \\
\hline \multirow{2}{*}{ Total } & $\mathrm{n}$ & 363 & 414 & 126 & 903 \\
\hline & $\%$ & $40.20 \%$ & $45.80 \%$ & $14.00 \%$ & $100.00 \%$ \\
\hline \multicolumn{6}{|l|}{ Caring for body parts } \\
\hline \multirow{2}{*}{ No difficulties } & $\mathrm{n}$ & 320 & 310 & 57 & 687 \\
\hline & $\%$ & $35.40 \%$ & $34.30 \%$ & $6.30 \%$ & $76.10 \%$ \\
\hline \multirow{2}{*}{ Moderate-weak difficulty } & $\mathrm{n}$ & 20 & 47 & 22 & 89 \\
\hline & $\%$ & $2.20 \%$ & $5.20 \%$ & $2.40 \%$ & $9.90 \%$ \\
\hline \multirow{2}{*}{ Moderate- intense difficulty } & $\mathrm{n}$ & 19 & 46 & 25 & 90 \\
\hline & $\%$ & $2.10 \%$ & $5.10 \%$ & $2.80 \%$ & $10.00 \%$ \\
\hline
\end{tabular}


Table 2 - (continuation)

\begin{tabular}{|c|c|c|c|c|c|}
\hline \multirow{2}{*}{ Variables } & & \multicolumn{3}{|c|}{ Age - categorized (years) } & \multirow{2}{*}{ Total } \\
\hline & & $65-74$ & $75-84$ & 85 and over & \\
\hline \multirow{2}{*}{ Complete difficulty } & $\mathrm{n}$ & 4 & 11 & 22 & 37 \\
\hline & $\%$ & $0.40 \%$ & $1.20 \%$ & $2.40 \%$ & $4.10 \%$ \\
\hline \multirow{2}{*}{ Total } & $\mathrm{n}$ & 363 & 414 & 126 & 903 \\
\hline & $\%$ & $40.20 \%$ & $45.80 \%$ & $14.00 \%$ & $100.00 \%$ \\
\hline \multicolumn{6}{|l|}{ Toileting } \\
\hline \multirow{2}{*}{ No difficulty } & $\mathrm{n}$ & 351 & 383 & 98 & 832 \\
\hline & $\%$ & $38.90 \%$ & $42.40 \%$ & $10.90 \%$ & $92.10 \%$ \\
\hline \multirow{2}{*}{ Weak, moderate or intense difficulty } & $\mathrm{n}$ & 8 & 22 & 16 & 46 \\
\hline & $\%$ & $0.90 \%$ & $2.40 \%$ & $1.80 \%$ & $5.10 \%$ \\
\hline \multirow{2}{*}{ Complete Difficulty } & $\mathrm{n}$ & 4 & 9 & 12 & 25 \\
\hline & $\%$ & $0.40 \%$ & $1.00 \%$ & $1.30 \%$ & $2.80 \%$ \\
\hline \multirow{2}{*}{ Total } & $\mathrm{n}$ & 363 & 414 & 126 & 903 \\
\hline & $\%$ & $40.20 \%$ & $45.80 \%$ & $14.00 \%$ & $100.00 \%$ \\
\hline \multicolumn{6}{|l|}{ Dressing } \\
\hline \multirow{2}{*}{ No difficulty } & $\mathrm{n}$ & 345 & 371 & 90 & 806 \\
\hline & $\%$ & $38.20 \%$ & $41.10 \%$ & $10.00 \%$ & $89.30 \%$ \\
\hline \multirow{2}{*}{ Weak - moderate difficulty } & $\mathrm{n}$ & 7 & 15 & 7 & 29 \\
\hline & $\%$ & $0.80 \%$ & $1.70 \%$ & $0.80 \%$ & $3.20 \%$ \\
\hline \multirow{2}{*}{ Moderate-intense difficulty } & $\mathrm{n}$ & 7 & 16 & 9 & 32 \\
\hline & $\%$ & $0.80 \%$ & $1.80 \%$ & $1.00 \%$ & $3.50 \%$ \\
\hline \multirow{2}{*}{ Complete difficulty } & $\mathrm{n}$ & 4 & 12 & 20 & 36 \\
\hline & $\%$ & $0.40 \%$ & $1.30 \%$ & $2.20 \%$ & $4.00 \%$ \\
\hline \multirow{2}{*}{ Total } & $\mathrm{n}$ & 363 & 414 & 126 & 903 \\
\hline & $\%$ & $40.20 \%$ & $45.80 \%$ & $14.00 \%$ & $100.00 \%$ \\
\hline
\end{tabular}

Among the environmental factors, the authors emphasize personal care providers and personal assistants. It was determined that $19.4 \%$ of the people say that they need support in daily personal care. The age ranges $75-84$ and 85 years and most need routine personal care ( $p$-value Chi-Square Tests $<0.001)$. These values are in contrast to those mentioned concerning self care and the carrying out of daily routines.

\section{Discussion of data}

It is not easy to discuss the data presented because there are few studies - whose objective is to investigate functioning in the elderly - based in populational samples and based in the ICF. In spite of this, the authors can highlight some of those which they consider more significant.

In relation to the socio-demographic data, what stands out is the predominance of the women in all of the age groups considered. If one considers the totality of the sample, there is a masculinity ratio of 76 , compared to 72.4 which is the masculinity ratio for the population of Portugal in general, aged 65 and over(8). This difference is congruent with all the other indicators relative to ageing in the Alentejo region, which confirm it to be a region with a particularly elderly population. On the other hand, the most recent data ${ }^{(8)}$ show that the imbalance in the ratio of men to women, with the latter predominating, is accentuated as age advances, and further - that this process has become more pronounced over the last few years.

The data relating to level of schooling, like those relating to the activities of reading and writing, contrast with the data according to which $34.6 \%$ of the elderly persons have no schooling at all(7). They also contrast with the data from the 2001 Employment Survey(7), through which the educational levels of the elderly population were determined, based on the categories of the International Standard Classification of Education (ISCED). According to that survey, more than half of the population aged 65 or over (55.1\%) had no education at all. This proportion was higher in the case of women (64.7\%, as against $41.3 \%$ for men). Comparing the data from these entities with that from the present study, it was determined that since 2001 a considerable reduction had been ascertained in the number of elderly people who couldn't read or write. It was also verified that there is an important difference between the declared level of schooling and the observed ability to 
read and write. Lastly, the elderly population generally continues to have low levels of schooling, and within this category, women have lower levels than the men.

Regarding the close family network, the authors emphasize the high percentage of elderly people who live alone $(23 \%)$. Concerning self-assessment of financial situation, the authors stress the similarity between this data and that provided by the Eurostat ${ }^{(14)}$ on the risk of poverty among the elderly. The authors thus ascertained that this reduced systematically between 2004 and 2009, although in 2010 there was an inversion in the tendency, with it rising to $21.0 \%$.

Among the data relating to functionality, the authors start by referring to the Body functions, specifically, to the functions of orientation and memory. A study undertaken with the objective of investigating memory complaints in people aged 65 or over in Madrid concluded that $32.4 \%$ of the individuals reported subjective memory complaints(15). These complaints' prevalence depended on age, education, sex, mood, and cognitive performance. The subjective complaints increased from $24 \%$ in the age groups 65 - 69 to $57 \%$ in the group aged 90 or over. On the other hand, through cognitive tests of orientation, it was noticed that individuals with orientation problems (81\%) have a frequency of $22.2 \%$ of subjective complaints of memory, while the individuals who fail all the items of orientation (4\%) have a frequency of complaints of $93 \%$. Apart from the methodological differences in this function's evaluation, there are considerable differences between the two studies' data, which demand that further studies be undertaken - not only to investigate the prevalence, but also to investigate the specific characteristics of this change.

The sleep functions deserve special attention, because approximately $1 / 4$ of the sample present some level of difficulty, denoting that sleep quality is being compromised. Reparative sleep is an important factor for preserving health and quality of life (16). Quality of sleep is associated with age, as sleep disorders occur more frequently after the age of 75 . Almost half of older adults report difficulty in getting to sleep and remaining so(17). In its turn, an epidemiological study undertaken in a district in Italy(18) concluded that insomnia was observed in $44.2 \%$ of the population, while drowsiness was found in $31.3 \%$, snoring in $47.2 \%$ and sleep apnea in $9.0 \%$. Considering this, it may be affirmed that the data presented here fit in among the complaints associated with this stage of life, which does not mean that they do not deserve every care and attention, even if only because of this function's interference in many others, such as in the carrying out of the activities of participation.

As mentioned above, concerning the hearing functions, $15.6 \%$ of the elderly present some level of difficulties requiring care, this being more evident in individuals aged between 75 and 84 years. According to one nationwide study carried out in the United States of America(19), approximately $30 \%$ of people aged between $65-79$, and $37 \%$ aged 80 or over, have loss of hearing capacity. In two studies carried out with Latin-American populations, and based on self-reported data, it was concluded that hearing loss affects $25-58 \%$ of people aged 65 or over ${ }^{(20-21)}$.

In the functions of pain, the problem is more serious, with approximately $58 \%$ of the sample to be included among those requiring care. Another study concluded that $39.9 \%$ of a sample of elderly people in the suburban zone of London had experienced pain in the previous four weeks(22). In its turn, a study carried out by the University of Texas Medical School, undertaken with a sample population of Mexican-Americans aged 74 or over, concluded that $64.7 \%$ referred to having pain in the previous four weeks, and that $49.7 \%$ reported that this pain had interfered with carrying out their activities of living. For women, low levels of schooling, fragility, reduced mobility, incapacity, elevated comorbidity and BMI, and symptoms of depression are significantly associated with the intensity of the pain and the interference with the activities of living.

It therefore seems that pain is an altered function in a high percentage of the elderly population. This is a problem because of both the pain itself, and because of where it mainly occurs, which without doubt induce greater levels of immobility. For these reasons it requires an appropriate intervention.

In the activities included in the self-caring group it may be ascertained that a percentage of people (between 4 and 14\%) have difficulties which require therapeutic care, and that there is a statistically significant association with age.

In a cross-sectional populational study of elderly (aged 60 or over) residents of the urban zone of the city of Ubá, in the state of Minas Gerais, Brazil, the result found after evaluation of the scores on a scale of self-perceived functional capacity in the ADL (Activities of Daily Living)(23) determined that $20.2 \%$ were in the first three levels of classification (very bad, bad, and average) and presented dependency in at least one ADL. Classification as 'good' or 'very good' was observed in 
$79.8 \%$ of the individuals studied. Some type of functional limitation was observed in $44.6 \%$ of the elderly people, and total incapacity in $2.0 \%$. When the association with the distinct age ranges was verified, it was observed that increase in age entails greater compromise in functional capacity.

\section{Conclusion}

The development of this study allowed the taking of decisive steps in the creation of the Core Set for the Elderly. Through the work done, the conditions have been created for continuing the development of this instrument, which may be transformed into a transprofessional instrument for the evaluation of functionality and care needs for the elderly.

Additionally, this study allowed the investigation of the functionality and care needs of the elderly in the Alentejo region, based on an evaluation based on the ICF. This allows one to see the situation in perspective, that is, considering the elderly people's bio-psycho-social dimensions. Thus, based in the data presented, one can understand that the elderly people's functionality is maintained at high percentages until about the age of 75. From that age onward, a progressive decline may be ascertained, with increasing percentages developing difficulties which require therapeutic help. It can be seen that low literacy, as well as financial difficulties, can constitute obstacles to functioning - and consequently to the elderly people's health conditions.

Based in this study's data, it is possible to envision an intervention directed at this population group's needs, setting out integrated measures which would allow the development of factors promoting health and reducing this population group's medicalization.

\section{Acknowledgment}

To Prof. Dr. Felismina Mendes (University of Évora) by indispensable cooperation given to this project.

\section{References}

1. United Nations, Department of Economic and Social Affairs, Population Division (UN). Total dependency ratio $(<20 \& 65+) /(20-64)$ by major area, region and country, 1950-2100 (ratio of population 0-19 and 65+ per 100 population. World Population Prospects: The 2010 Revision. Feb 2011.

2. Lafortune G, Balestat G. Trends in severe disability among elderly people: assessing the evidence in 12 oecd countries and the future implications. OECD Papers. 2007;7(3):1-79.

3. Dionísio BM. Os velhos ao espelho e o reflexo dos outros: imagens, percepções e atitudes em torno da velhice. In: Fórum Sociológico, no 5/6. Lisboa; 2001. p. 241-55.

4. Direcção-Geral da Saúde (DGS). Classificação Internacional de Funcionalidade, Incapacidade e Saúde. Lisboa: Organização Mundial da Saúde; nov 2004. (resolução WHA54.21).

5. Cieza A, Boldt C, Ballert C, Eriks-Hoogland I, Bickenbach J, Stucki G. Setting Up a Cohort Study on Functioning: Deciding What to Measure. Am J Phys Med Rehab. 2011;90:S17-28.

6. Marengoni A, Agüero-Torres H, Timpini A, Cossi S, Fratiglioni L. Rehabilitation and nursing home admission after hospitalization in acute geriatric patients. J Am Med Directors Assoc. 2008;9(4):265-70.

7. Instituto Nacional de Estatística (PT). As pessoas. [Internet]. jan 2011. [acesso 12 mai 2012]; ISBN 978-989-25-0074-4. Disponível em: http:// www.ine.pt/xportal/xmain?xpid=INE\&xpgid=ine publicacoes\&PUBLICACOESpub_boui $=108445117 \&$ PUB LICACOESmodoINE, 2011

8. Escorpizo R, Finger M, Glässel A, Gradinger $F$, Lückenkemper M, Cieza A. A Systematic Review of Functioning in Vocational Rehabilitation Using the International Classification of Functioning, Disability and Health. J Occup Rehab. 2011;21(2):134-46.

9. Kostanjsek N, Rubinelli S, Escorpizo R, Cieza A, Kennedy $C$, ÜÜstüün $T$, et al. Assessing the impact of health conditions using the ICF. Disabil Rehab. 2011;33(15/16):1475-82.

10. Zhao J, Liao D, McMahon B, O'Donovan D, Schiretz $\mathrm{R}$, Gregersen $\mathrm{H}$, et al. Functional luminal imaging probe geometric and histomorphologic analysis of abdominal wall wound induced by different trocars in pigs. Surgical Endoscopy. 2009;23(5):1004-12.

11. Ebrahim S, Adamson J, Ayis S, Beswick A, Gooberman-Hill R. Locomotor disability: meaning, causes and effects of interventions. J Health Services Res Policy. 2008;1338-46.

12. Grill E, Stucki G. Criteria for validating comprehensive ICF Core Sets and developing brief ICF Core Set versions. J Rehab Medicine (Stiftelsen Rehabiliteringsinformation). 2011;43(2):87-91.

13. Pereira C, Fonseca C, Escoval A, Lopes M. Contributo para a classificação da funcionalidade na população com mais de 65 anos, segundo a classificação internacional de funcionalidade. Rev Portuguesa Saúde Pública. 2011;19(1):52-62 
14. European Commission. Demographic balance and crude rates. European Commision Statistical Office of the European Communities: Luxembourg [Internet]. jan 2011. [acesso 28 ago 2012]; Disponível em: http://epp.eurostat.ec.europa. eu/portal/page/portal/statistics/search_database.

15. Montejo P, Montenegro M, Fernandez M, Maestu F. Subjective memory complaints in the elderly: Prevalence and influence of temporal orientation, depression and quality of life in a population-based study in the city of Madrid. Aging Mental Health. 2011;15(1):85-96.

16. Heaton $P$, Williams K, Cummins O, Happé F. Autism and pitch processing splinter skills: a group and subgroup analysis. Autism: Int J Res Practice. 2008;12(2):203-19. 17. Roepke S, Ancoli-Israel S. Sleep disorders in the elderly. Indian J Med Res. 2010;131(2):302-10.

18. Bonanni E. Sleep disturbances in elderly subjects: an epidemiological survey in an Italian district. Acta Neurol Scand. 2010;122(6):389-97.

19. Caban A, Lee D, Gómez-Marín O, Lam B, Zheng D. Prevalence of concurrent hearing and visual impairment in US adults: the National Health Interview Survey, 1997-2002. Am J Public Health. 2005;95(11):1940-2.

20. Davanipour Z, Lu N, Lichtenstein M, Markides K. Hearing problems in Mexican American elderly. Am J Otol. 2000;21(2):168-72.

21. Torre $\mathrm{P}$, Moyer $\mathrm{C}$, Haro N. The accuracy of selfreported hearing loss in older Latino-American adults. Int J Audiol. 2006;45(10):559-62.

22. Iliffe $S$, Kharicha K, Carmaciu C, Harari D, Swift C, Stuck $A$, et al. The relationship between pain intensity and severity and depression in older people: exploratory study. BMC Fam Pract. 2009;10:54.

23. Nunes M, Ribeiro R, Rosado L, Franceschini S. The influence of sociodemographic and epidemiological characteristics on the functional capacity of elderly residents in the city of Ubá, Minas Gerais [Portuguese]. Rev Bras Fisioter. 2009;13(5):376-82. 